DOE/MC/391001-96/C0535

\title{
Hot-Gas Filter Ash Characterization
}

Authors:

John P. Hurley

Tina M. Strobel

Bruce A. Dockter

\section{Contractor:}

University of North Dakota

Energy \& Environmental Research Center

P.O. Box 9018

Grand Forks, ND 58202-9018

PREEIVED

HOV - 31995

OSTI

\section{Contract Number:}

RP3910-01

Conference Title:

Advanced Coal-Fired Power Systems '95 Review Meeting

Conference Location:

Morgantown, West Virginia

\section{Conference Dates:}

June 27-29, 1995

\section{Conference Sponsor:}

U.S. Department of Energy, Morgantown Energy Technology Center (METC) 


\section{DISCLAIMER}

This report was prepared as an account of work sponsored by an agency of the United States Government. Neither the United States Government nor any agency thereof, nor any of their employees, makes any warranty, express or implied, or assumes any legal liability or responsibility for the accuracy, completeness, or usefulness of any information, apparatus, product, or process disclosed, or represents that its use would not infringe privately owned rights. Reference herein to any specific commercial product, process, or service by trade name, trademark, manufacturer, or otherwise does not necessarily constitute or imply its endorsement, recommendation, or favoring by the United States Government or any agency thereof. The views and opinions of authors expressed herein do not necessarily state or reflect those of the United States Government or any agency thereof.

This report has been reproduced directly from the best available copy.

Available to DOE and DOE contractors from the Office of Scientific and Technical Information, 175 Oak Ridge Turnpike, Oak Ridge, TN 37831; prices available at (615) 576-8401.

Available to the public from the National Technical Information Service, U.S. Department of Commerce, 5285 Port Royal Road, Springfield, VA 22161; phone orders accepted at (703) 487-4650. 


\section{CONTRACT INFORMATION}

Contract Number

Contractor

Other Funding Sources

Contractor Project Manager

Principal Investigators

METC Project Manager

Period of Performance

Schedule and Milestones
RP3910-01

Energy \& Environmental Research Center University of North Dakota

PO Box 9018

Grand Forks, ND 58202-9018

(701) 777-5000 (telephone)

(701) 777-5181 (fax)

Electric Power Research Institute (EPRI)

Consortium

John P. Hurley

John P. Hurley

Tina M. Strobel

Bruce A. Dockter

Norman T. Holcombe

May 1, 1994, through April 30, 1997

FY95 Program Schedule

$\begin{array}{lllllllllllll}\mathrm{S} & \mathrm{O} & \mathrm{N} & \mathrm{D} & \mathrm{J} & \mathrm{F} & \mathrm{M} & \mathrm{A} & \mathrm{M} & \mathrm{J} & \mathrm{J} & \mathrm{A}\end{array}$

Task 1 - Field Sampling and Archive

Sample Analysis

Task 2 - Laboratory-Scale Testing

Task 3-Bench-Scale Testing

Task 4-Computer Modeling 


\section{OBJECTIVES}

One of the key difficulties in the development of advanced pressurized fluidizedbed combustion (PFBC) and integrated gasification combined-cycle (IGCC) systems is the need to remove particulates from the gas stream at high temperatures and pressures. For over ten years, both U.S. Department of Energy (DOE) Morgantown Energy Technology Center (METC) and Electric Power Research Institute (EPRI) have been sponsoring research devoted to solving problems in pilot- and commercial-scale PFBCs and IGCCs and their associated hot-gas cleanup systems. This research has revealed numerous cases of ash cake buildup on filter elements that has been difficult to remove using on-line jet pulsing. The objectives of this research are to 1) determine the mechanisms by which a difficult-to-clean ash is formed and how it blinds or bridges hot-gas filters, 2) develop a method to determine the rate of blinding or bridging based on analyses of the feed coal and sorbent and on the operating conditions, and 3) provide suggestions for ways to prevent filter blinding and bridging by the troublesome ash.

\section{BACKGROUND INFORMATION}

Large-scale hot-gas filter testing has revealed numerous cases of cake buildup on filter elements that has been difficult, if not impossible, to remove. At times, the cake can bridge between candle filters, leading to high filter failure rates. It is speculated that chemical as well as physical effects are playing a role in helping to bond the ash to the filter or to itself. These factors include particle-size and composition distribution, particle shape, gas condensation, the aerodynamics of deposition, and system temperature. The Energy \& Environmental Research Center (EERC) is working with EPRI and a consortium of companies in partnership with DOE METC to perform the research necessary to determine the relative importance of these factors in causing hot-gas cleanup filters to be blinded by ash or to develop deposits that can bridge the filters and cause them to fail. The primary deliverable will be a graphics-driven computer model that can be used to predict and control the problems based on data from the analyses of coal and sorbent, as well as system operating parameters.

\section{PROJECT DESCRIPTION}

This research is examining ashes from largescale filters, ashes originally from large-scale PFBCs or gasifiers which have been reentrained in a laboratory-scale rig and deposited on filters in simulated filtration environments, and newly generated ashes from small pilot- or bench-scale facilities where parametric evaluations will be employed. The problem is being defined through full-scale sampling. Parametric testing will be done at the lab, bench, and pilot scale to determine the factors leading to the problem. Finally, the data will be used to develop a userfriendly computer model to help predict the occurrence of the problem, choose appropriate fuels or operating conditions, or design the system to reduce the blinding and bridging problems. Solutions predicted by the model will be tested on the bench scale.

Four tasks are being performed:

- Task 1 - Field Sampling and Archive Sample Analysis

- Task 2-Laboratory-Scale Testing

- Task 3-Bench-Scale Testing

- Task 4-Computer Modeling

The initial stages of the project have focused on determining chemical, mineralogical, and 
physical characteristics of archive and on-line PFBC and IGCC coal, sorbent, bed ash, cyclone ash, and filter samples. To date, filter fines collected from four runs of the Grimethorpe PFBC, and coal, sorbent, bed ash, cyclone ash, and filter fines collected from three test series of the Tidd PFBC were characterized using several standard and advanced analytical techniques. The filter fine samples represent ashes of varying cleanability from both systems. Standard analytical techniques included $\mathrm{x}$-ray fluorescence (XRF) for bulk chemistry and $\mathrm{x}$-ray diffraction (XRD) for mineralogy, and advanced analytical techniques included a developmental scanning electron microscopy (SEM) technique to determine particle-size and composition distributions of sub- and supermicron ash on a particle-by-particle basis. Scanning auger electron spectroscopy was used to determine surface chemistry of the ash particles.

\section{RESULTS}

\section{Task 1 - Field Sampling and Archive Sample Analysis}

The objectives of Task 1 are to determine the mechanisms by which difficult-to-clean ash is formed and how it blinds or bridges hot-gas filters. The analyses of many samples from various systems and operating conditions are necessary to fully characterize ash-bridging mechanisms, such as initial stickiness of ash and long-term sintering processes. The two sources for samples are on-line field sampling during the project and analyses of archive samples collected by project sponsors. To date, we have been able to acquire samples from several test series of the Tidd PFBC and four archive samples from the Grimethorpe PFBC. We have also received two samples each from the Filter Development Rig and the Gas Utilization Facility Filter from British Coal.

Tidd PFBC. The American Electric Power Service Corporation (AEP) and Ohio Power Company donated filter ash samples from several test series of the Westinghouse advanced particle filter (APF) assembly at the Tidd PFBC Demonstration Plant (1). The samples were collected by METC and Southern Research Institute (SRI) in May and October 1994. Filter fines were collected in February 1995 by AEP and sent to the EERC. AEP has also provided the EERC with archived coal, coal slurry, sorbent, bed ash, and cyclone ash for some of these tests at Tidd.

The APF experienced ash bridging and pressure drop increases during the first test series (May 1994 samples) while firing a Pittsburgh No. 8 coal and a Plum Run Greenfield dolomite. There was buildup of ash on all filters. During the next test series, July through November 1994, some filter candles appeared clean, with some ash cake on others. Testing at Tidd during 1995 has shown less ash buildup on filters because of complete spoiling of the cyclone (P11) upstream of the APF (the P11 cyclone was only partially spoiled during testing in 1994). A summary of the operation of the Tidd PFBC and APF are shown in Table 1. Chemical and mineralogical characterization were performed on the samples from these test series at the Tidd PFBC.

Bulk Chemistry and Mineralogy. Proximate analyses indicate differences in moisture and volatile contents for the Tidd filter ash samples. The May and October 1994 samples were collected from residual filter cakes, whereas the February 1995 sample was from the APF ash hopper. The May 1994 ash contains up to $3 \mathrm{wt} \%$ moisture, whereas the other two ashes contain less than $0.5 \mathrm{wt} \%$ moisture. The higher moisture in 
Table 1. Operating Conditions at the Tidd PFBC

\begin{tabular}{|c|c|c|c|}
\hline Parametert, & \% Nay 1994 & 120 cteber 1994 & ffebruat 1995 \\
\hline Coal & Pittsburgh No. 8 & Pittsburgh No. 8 & Pittsburgh No. 8 \\
\hline Sorbent & Dolomite & $\begin{array}{l}\text { Dolomite and } \\
\text { Limestone }\end{array}$ & Dolomite \\
\hline Bed Temperature, ${ }^{\circ} \mathrm{C}\left({ }^{\circ} \mathrm{F}\right)$ & $818(1504)$ & $855(1571)$ & $861(1581)$ \\
\hline Cyclone Inlet Temp., ${ }^{\circ} \mathrm{C}\left({ }^{\circ} \mathrm{F}\right)$ & 748 (1378) & $793(1385)$ & $799(1471)$ \\
\hline APF Inlet Temp., ${ }^{\circ} \mathrm{C}\left({ }^{\circ} \mathrm{F}\right)$ & $727(1340)$ & $760(1400)$ & $802(1475)$ \\
\hline APF Pressure, psig & 129 & 129 & 137 \\
\hline Upstream P11 Cyclone & Partially spoiled & Partially spoiled & Completely spoiled \\
\hline
\end{tabular}

the May 1994 APF ashes may be related to conditions during operation or the presence of moisture during off-line sampling of the APF. The higher volatile matter content in the February 1995 ash is related to a higher carbonate content of this ash. The source of carbonate is the sorbent that was carried over from the bed to the APF. The carbonate was not calcined or sulfated in the APF.

Figure 1 shows the averaged XRF results for the three Tidd filter ash samples collected in May 1994, October 1994, and February 1995. The February 1995 ash contains less $\mathrm{SiO}_{2}$, $\mathrm{Al}_{2} \mathrm{O}_{3}$, and $\mathrm{SO}_{3}$ and more $\mathrm{CaO}$ and $\mathrm{MgO}$ than the other two ashes. XRD results also show that the mineralogy of the ashes differs. The May and October 1994 ashes contain calcium magnesium sulfate and anhydrite and the major phases, whereas only anhydrite is a major phase in the February 1995 ash. The February ash also contains minor amounts of carbonate phases, such as calcite and dolomite, whereas the other two ashes contain no carbonates. The presence of the carbonates and $\mathrm{CO}_{2}$ indicates that the February 1995 filter ash is relatively fresh and that the sorbent has not all calcined or sulfated. According to engineers at Tidd, the cyclone upstream of the APF was completely spoiled during all of the 1995 testing, therefore much larger particles were entering the filter vessel. These larger particles are not as easily sulfated because of the lower surface area-tovolume ratio as smaller, submicron particles. These results may indicate that the submicron sulfur-containing ash plays a role in ash bridging as the prevalence of this type of ash in the 1994 samples was accompanied by more dust buildup on the filters than testing in 1995 .

Samples of coal, sorbent, and cyclone and bed ash were analyzed for runs occurring in the same time frame as the collection of the APF ashes. Complete sample sets were available for all except the May 1994 test. Bulk chemistries of these samples are illustrated in Figures 2 through 4. The usefulness of the bulk chemistries is to determine mineral and chemical interactions occurring from the bed to the APF that may influence behavior of the ash in the APF. For all of the three tests, Pittsburgh No. 8 coal was the fuel injected as a slurry, with 


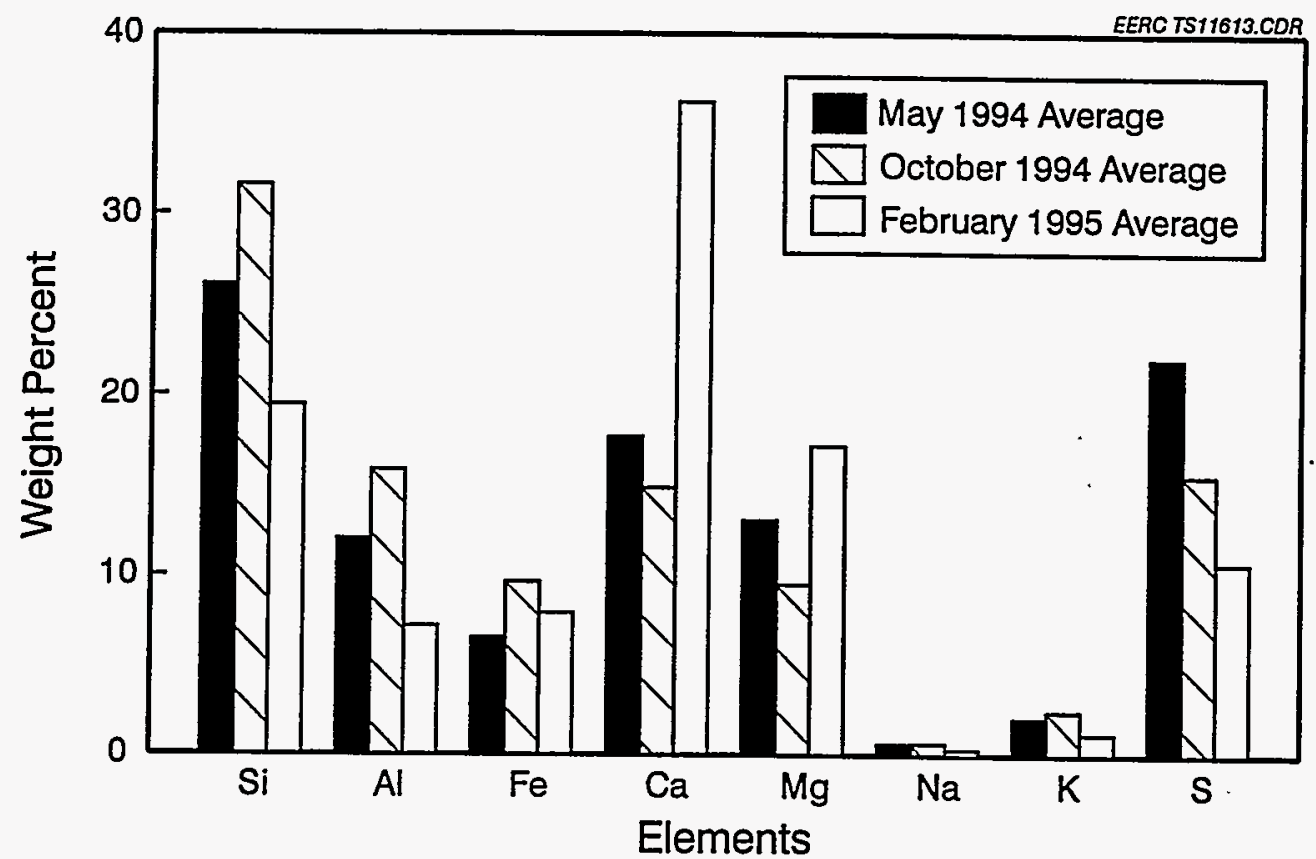

Figure 1. Averaged XRF Results for the APF Tidd Ashes from May 1994, October 1994, and February 1995

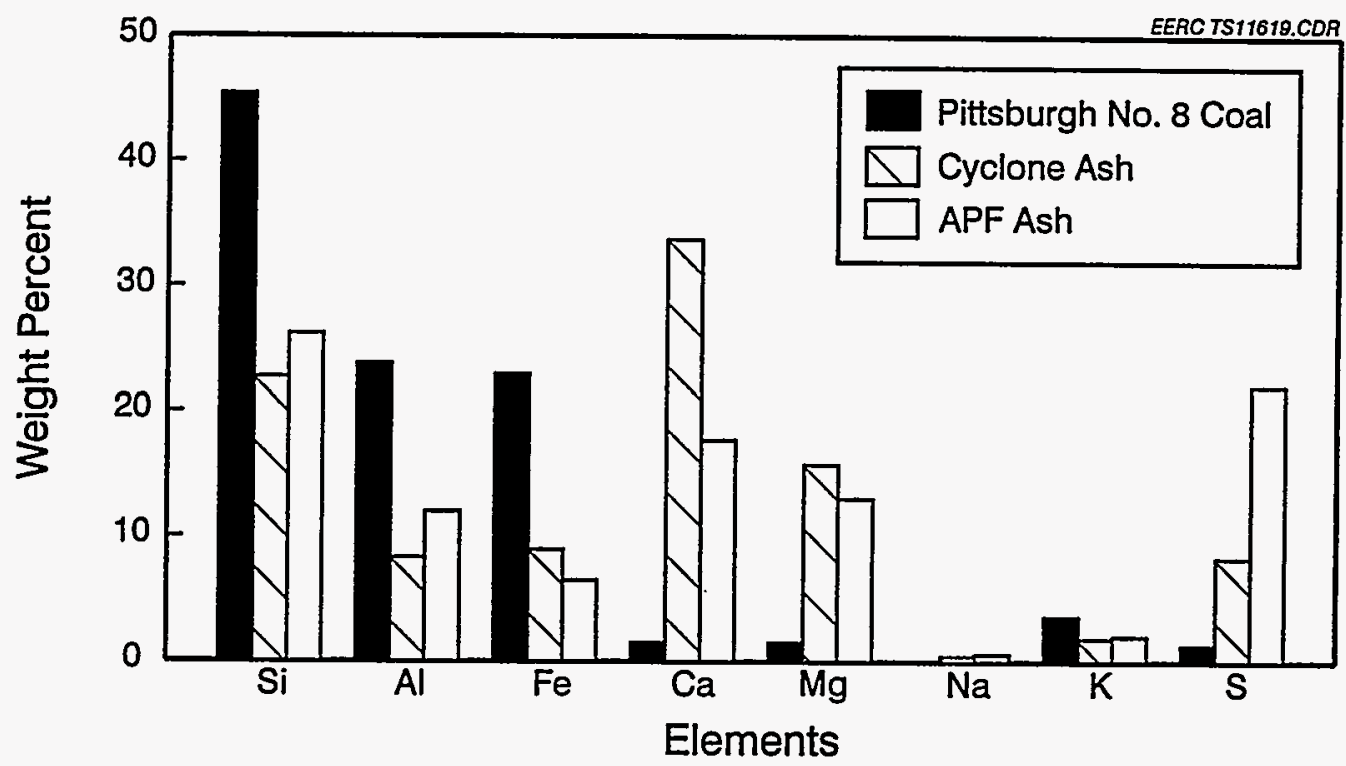

Figure 2. XRF Results for the Tidd Samples from Test No. 51 Conducted in May 1994 


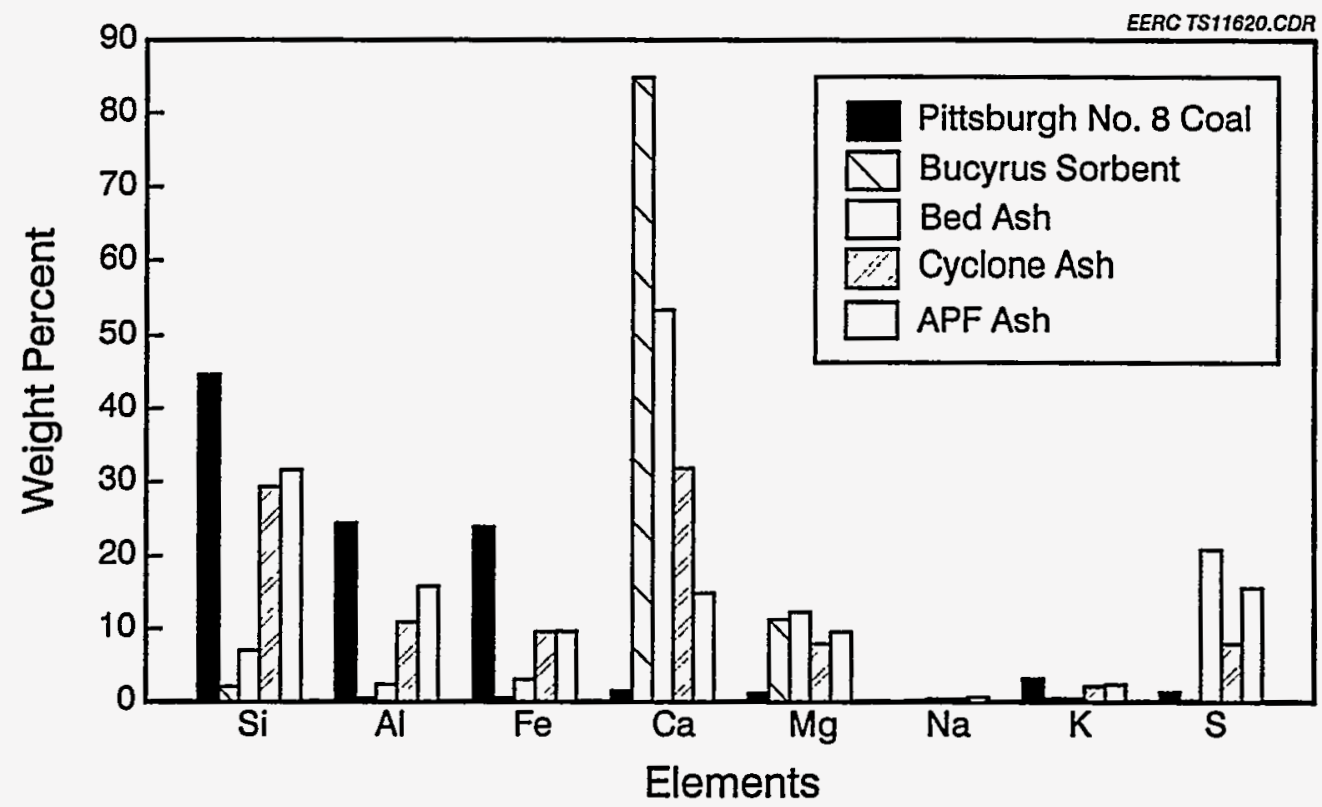

Figure 3. XRF Results for the Tidd Samples from Test No. 78 Conducted in October 1994

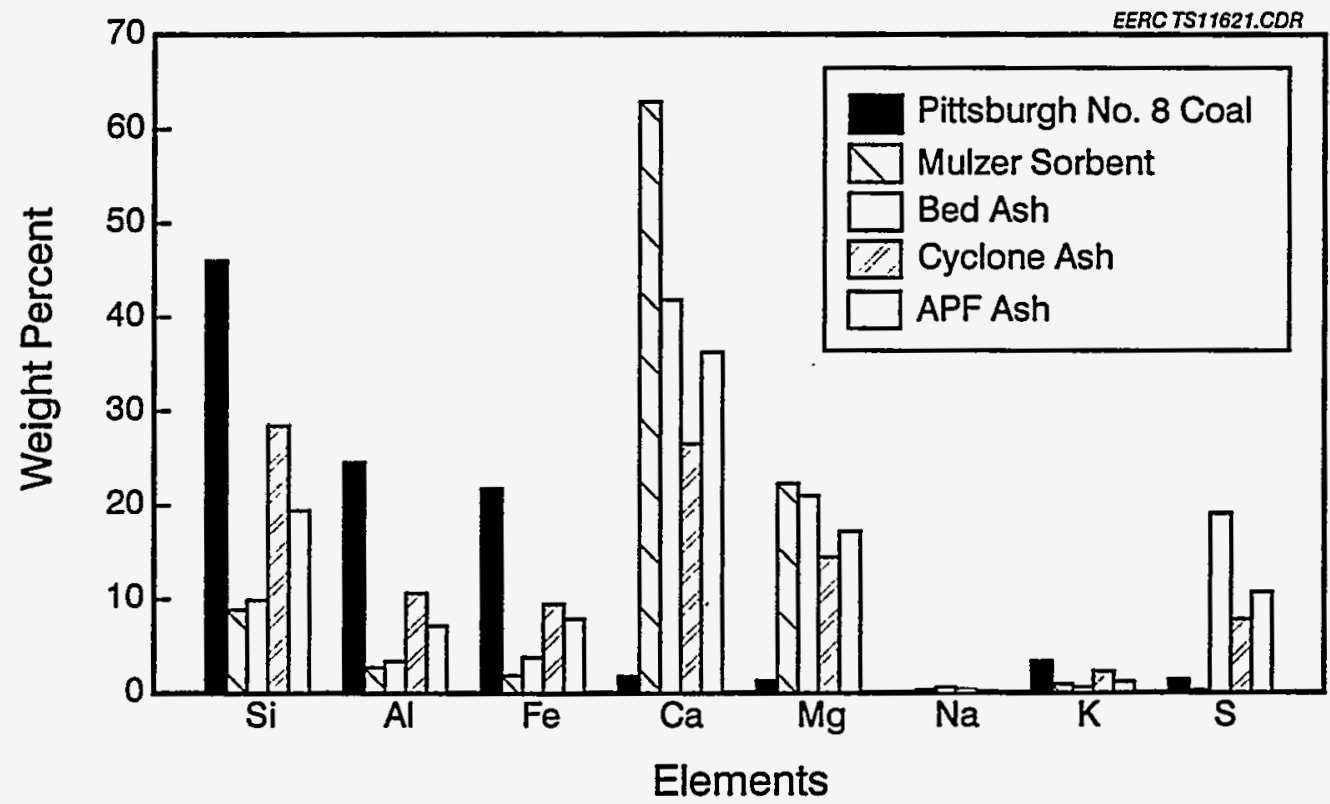

Figure 4. XRF Results for the Tidd Samples from Test No. 87 Conducted in February 1995 
paste moistures ranging from 24 to $28 \mathrm{wt} \%$. The sorbents used were dolomites in Tests No. 51 (May 1994) and No. 87 (February 1995), and limestone in Test No. 78 (October 1994).

Results for Test No. 51 show that the APF ash contains greater amounts of $\mathrm{SO}_{3}$ and less $\mathrm{CaO}$ and $\mathrm{MgO}$ than the cyclone ash (Figure 2). Test No. 78 shows a trend of decreasing $\mathrm{CaO}$ and increasing $\mathrm{SiO}_{2}$ from the bed ash to the APF ash (Figure 3). The results for Test No. 87 show that there is preferential removal of aluminosilicate-rich particles before the APF, and the APF ash is enriched in calcium magnesium sulfate-rich particles (Figure 4). Results from XRD may be able to confirm these interpretations. The bulk compositions of the coal from the three tests were identical.

Fine Particle Analysis. An automated SEM technique to determine the chemical composition distribution, size distribution, and shape of submicron particles is being developed under this project. Other researchers have used similar automated SEM techniques to characterize aerosol particles from 0.1 to $2.0 \mu \mathrm{m}$ collected on filters and coal ash from 1.0 to $100.0 \mu \mathrm{m}(2-4)$. Because of the submicron size of the APF ashes and the differing compositions when compared to aerosols and coal particles, modifications of these techniques were needed to develop a fine particle technique (FPT) for analyzing submicron coal ash.

The technique involves dispersing particles of ash on a vitreous carbon substrate using an organic solvent. The dispersion of the particles is necessary to avoid interaction of the $\mathrm{x}$-ray beam with particles adjacent to the particle of interest. The carbon substrate is used instead of mounting the ash in an epoxy plug to avoid the analysis of ash particles which may be below the particle of interest. The $\mathrm{x}$-ray beam scans across the sample locating, sizing, and analyzing up to 3000 particles per sample. These data are then reduced using a program called "Finepart," which categorizes the particles into phase groups based on chemistry. "Finepart" is a modification of "Partchar," which is used to reduce the data from a computer-controlled SEM analysis of coal or fly ash (3). Both programs were developed at the EERC. Originally, Finepart classified the raw data into 33 chemical composition categories for the ash particles ranging between 0.1 to $16 \mu \mathrm{m}$ in average diameter. The program is being altered to characterize ash particles ranging from 0.1 to $100.0 \mu \mathrm{m}$ in diameter to better characterize PFBC ashes.

FPT Analytical Results. The Tidd APF ashes from May and October 1994 were analyzed using the FPT. The results are given in Tables 2 and 3 and compared with XRF results. The samples were collected from the top and bottom plenums of the APF. The elemental determinations are within acceptable analytical error of $\pm 10 \%$ except for the $\mathrm{Si}$ weight percent for the bottom $B$ cake in October 1994. Further examination shows that the FPT seems to overestimate the Si when compared to the XRF results. Since the FPT analysis of the May and October samples only analyzed particles less than $16.0 \mu \mathrm{m}$, there may have been a tendency for particles composed of similar elements to form agglomerates which are larger than $16.0 \mu \mathrm{m}$ and were not analyzed. Also, there may be an inordinate number of $\mathrm{Si}$ particles present that are smaller than $16.0 \mu \mathrm{m}$.

In a PFBC, the size of the fly ash particles determine their collection efficiency and ability to form difficult-to-clean cakes. The size distributions using FPT for particles ranging from 0.1 to $16.0 \mu \mathrm{m}$ for the averaged May and October 1994 samples and for the February 
Table 2. Comparison of Analytical Techniques for the Tidd APF Ashes Collected in May 1994

\begin{tabular}{|c|c|c|c|c|}
\hline $4 \%$ & $\%$ & & 18.1 .2 .8$. & 4. \\
\hline & FPT & XRF & FPT & XRF \\
\hline $\mathrm{Na}$ & 0.1 & 0.6 & 0.2 & 0.6 \\
\hline $\mathrm{Mg}$ & 6.3 & 13.3 & 4.9 & 12.8 \\
\hline $\mathrm{Al}$ & 8.1 & 11.5 & 15.8 & 12.6 \\
\hline $\mathrm{Si}$ & 34.0 & 25.4 & 33.5 & 26.6 \\
\hline$P$ & 0.6 & 0.3 & 0.6 & 0.5 \\
\hline$S$ & 29.3 & 21.1 & 26.4 & 20.8 \\
\hline $\mathrm{K}$ & 3.4 & 1.9 & 3.1 & 2.0 \\
\hline $\mathrm{Ca}$ & 15.9 & 18.7 & 12.7 & 16.9 \\
\hline $\mathrm{Fe}$ & 1.2 & 6.5 & 1.7 & 6.5 \\
\hline $\mathrm{Ti}$ & 1.1 & 0.7 & 1.1 & 0.7 \\
\hline
\end{tabular}

Table 3. Comparison of Analytical Techniques for the Tidd APF Ashes Collected in October 1994

\begin{tabular}{|c|c|c|c|c|}
\hline \multicolumn{3}{|c|}{ 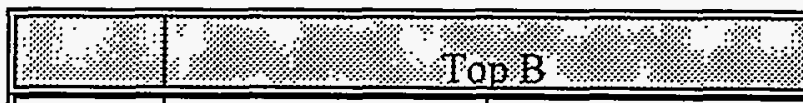 } & \multicolumn{2}{|c|}{ ( } \\
\hline & FPT & XRF & FPT & XRF \\
\hline $\mathrm{Na}$ & 0.1 & 0.6 & 0.3 & 0.6 \\
\hline $\mathrm{Mg}$ & 1.6 & 9.0 & 8.4 & 10.0 \\
\hline $\mathrm{Al}$ & 24,7 & 16.4 & 22.3 & 15.2 \\
\hline $\mathrm{Si}$ & 49.1 & 32.7 & 39.3 & 30.7 \\
\hline$P$ & 0.5 & 0.2 & 1.0 & 0.2 \\
\hline$S$ & 10.2 & 15.3 & 12.8 & 14.3 \\
\hline $\mathrm{K}$ & 4.2 & 2.4 & 4.7 & 2.2 \\
\hline $\mathrm{Ca}$ & 4.9 & 12.8 & 8.1 & 16.4 \\
\hline $\mathrm{Fe}$ & 3.7 & 9.7 & 2.0 & 9.7 \\
\hline $\mathrm{Ti}$ & 0.9 & 0.8 & 1.0 & 0.7 \\
\hline
\end{tabular}


1995 sample are shown in Figure 5. The FPT results indicate that the May and October 1994 particle-size distributions are smaller than the February 1995 sample. The larger particle-size distribution in the February 1995 sample may be due to complete spoiling of the cyclone upstream of the APF, which allowed larger ash particles to enter the filter vessel. The difference in the size distributions may also be related to the location of the samples; the 1994 samples are residual filter cakes whereas the February 1995 sample is from the APF hopper. Smaller particles may preferentially deposit on the filter cakes.

Figure 6 shows the comparison of the mineral composition for the $0.1-$ to $16.0-\mu \mathrm{m}$ particles for the May and October 1994 samples and for the February 1995 filter ash sample. It should be noted that the February 1995 APF ash contained a large percentage of particles in the greater than $16.0-\mu \mathrm{m}$ size range. Therefore, future FPT results will concentrate on the size range from 0.1 to $100.0 \mu \mathrm{m}$. For the smaller size range $(0.1$ to $16.0 \mu \mathrm{m})$, the amount of quartz was similar for the three samples, while the relative percentages of the other mineral classifications varied. The February 1995 sample contains less gypsum/Al-silicate and other Al-silicate phases such as kaolinite and montmorillonite than the 1994 ash samples. The presence of larger particles in this ash may have prevented sulfation, as larger particles are not as easily sulfated as smaller particles because of the lower surface area-to-volume ratio. Thus these results indicate that spoiling of the cyclone upstream of the APF resulted in larger particles entering the APF, and these larger particles possibly experienced less sulfation and less ash bridging.

SEM Morphology. The three Tidd APF ashes were also examined by SEM morphology.
The objective of the SEM examination was to determine differences in the chemical and physical nature of the February 1995 ash and the May and October 1994 ashes and how these differences relate to ash bridging. Calcium- and sulfur-rich particles were found in the May and October 1994 ashes, and many of these particles were agglomerated (Figure 7). The necks between the particles were composed either of sulfate-rich or silicate-rich material. Surface analyses of the ashes also indicated calciumand sulfur-rich areas in these neck areas, as well as segregation of calcium- and magnesium-rich areas in the bulk ash. Further analyses are needed to determine if this segregation is related to ash-bridging mechanisms.

SEM morphology of the February 1995 APF ash indicated less particle agglomeration. The main phases determined by SEM/energydispersive XRF included calcium magnesium sulfate, dolomite and calcite, quartz, hematite, and partially sulfated carbonate phases. Some dolomite grains were rimmed with sulfate, indicating only minor sulfation (Figure 8). Cross-sectioning the ash reveals some FPT limitations: coatings on particles are difficult to evaluate. Other phases present included aluminosilicates with $\mathrm{Ca}, \mathrm{Fe}$, and $\mathrm{Mg}$ as minor constituents. Some of the aluminosilicates also contained $\mathrm{Fe}$ and $\mathrm{K}$. Sintered and agglomerated particles were not as prevalent as in the May and October 1994 samples, and most of the particles were angular in shape.

Summary. Changes in ash behavior in the Tidd APF are related to system operation, such as complete spoiling of the P11 cyclone upstream of the APF. When the cyclone was completely spoiled during the February 1995 testing, much larger ash particles entered the APF. These larger particles differed in composition from the APF ash samples 


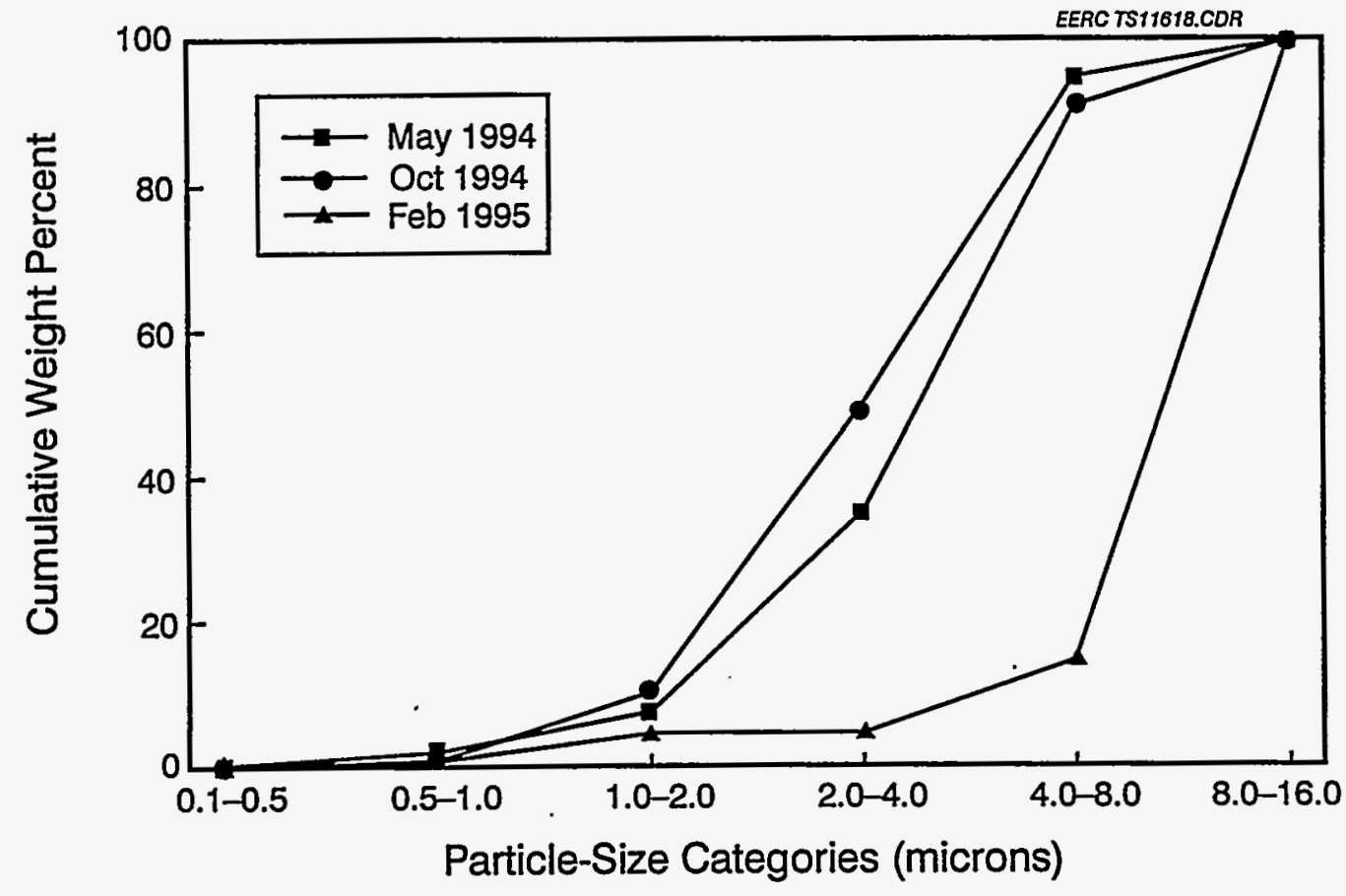

Figure 5. Particle-Size Distribution (cumulative weight percent) for the Averaged May and October 1994 and for the February 1995 Samples from the Tidd PFBC for the 0.1- to 16.0- $\mu \mathrm{m}$ Particles

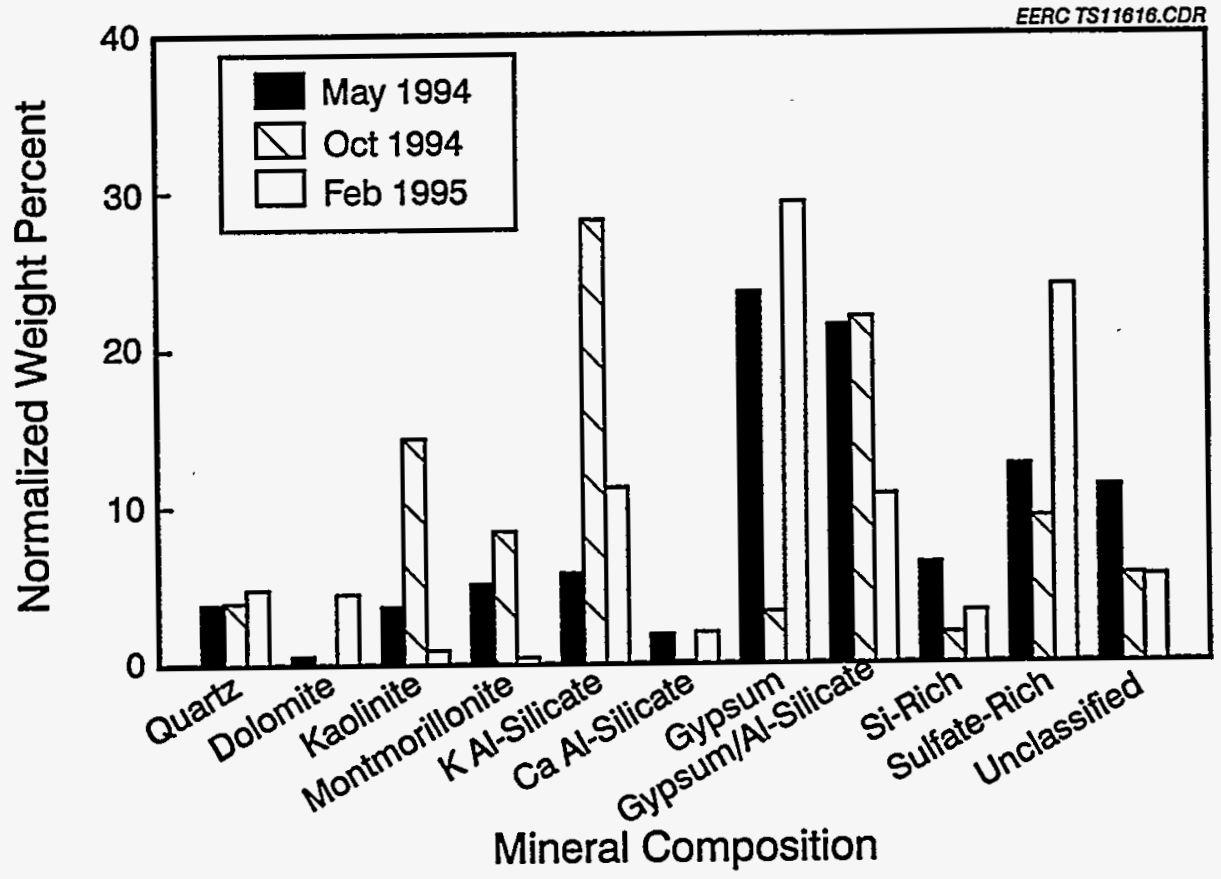

Figure 6. Composition Distribution for the Averaged May and October 1994 and February 1995 Samples for the Tidd PFBC for the 0.1- to 16.0- $\mu \mathrm{m}$ Particles (normalized weight percent) 


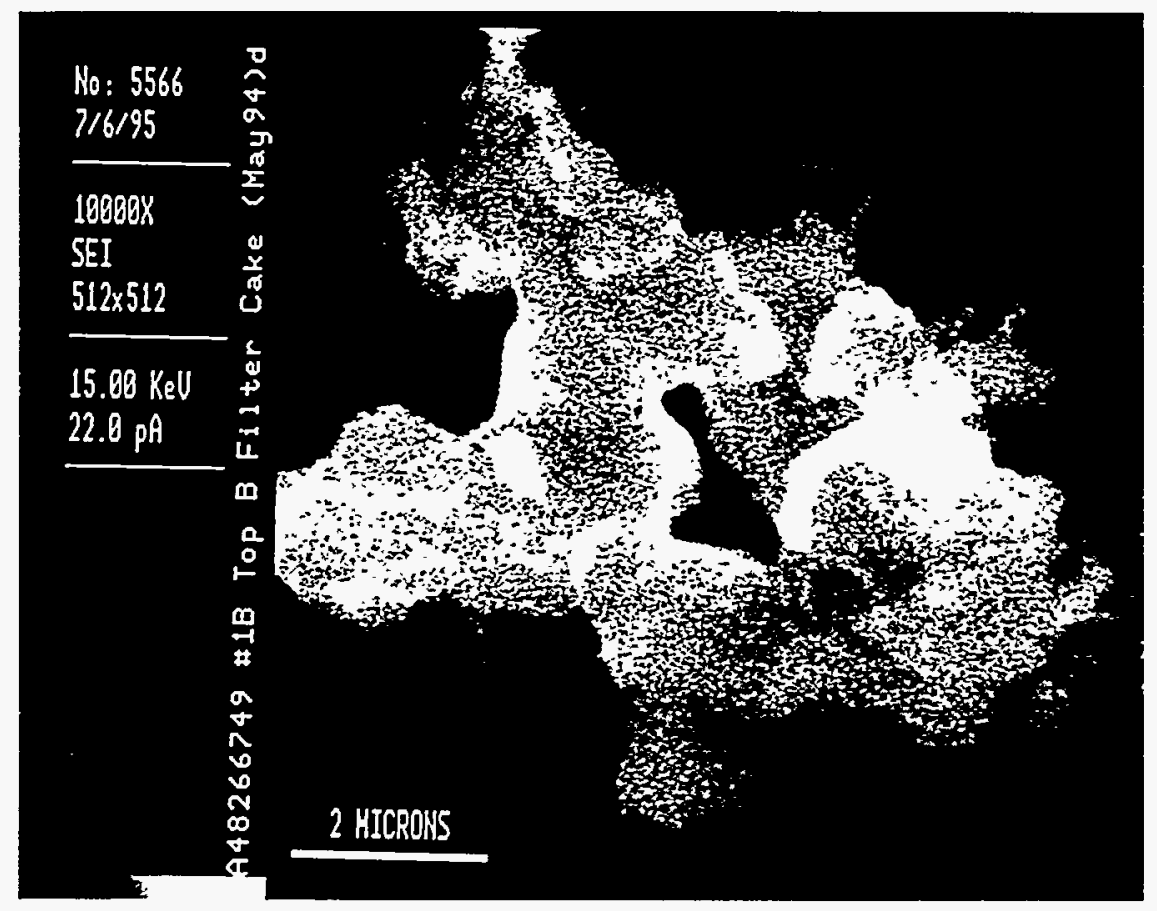

Figure 7. SEM Photo Showing an Agglomerated Particle from the May 1994 Tidd APF Ash

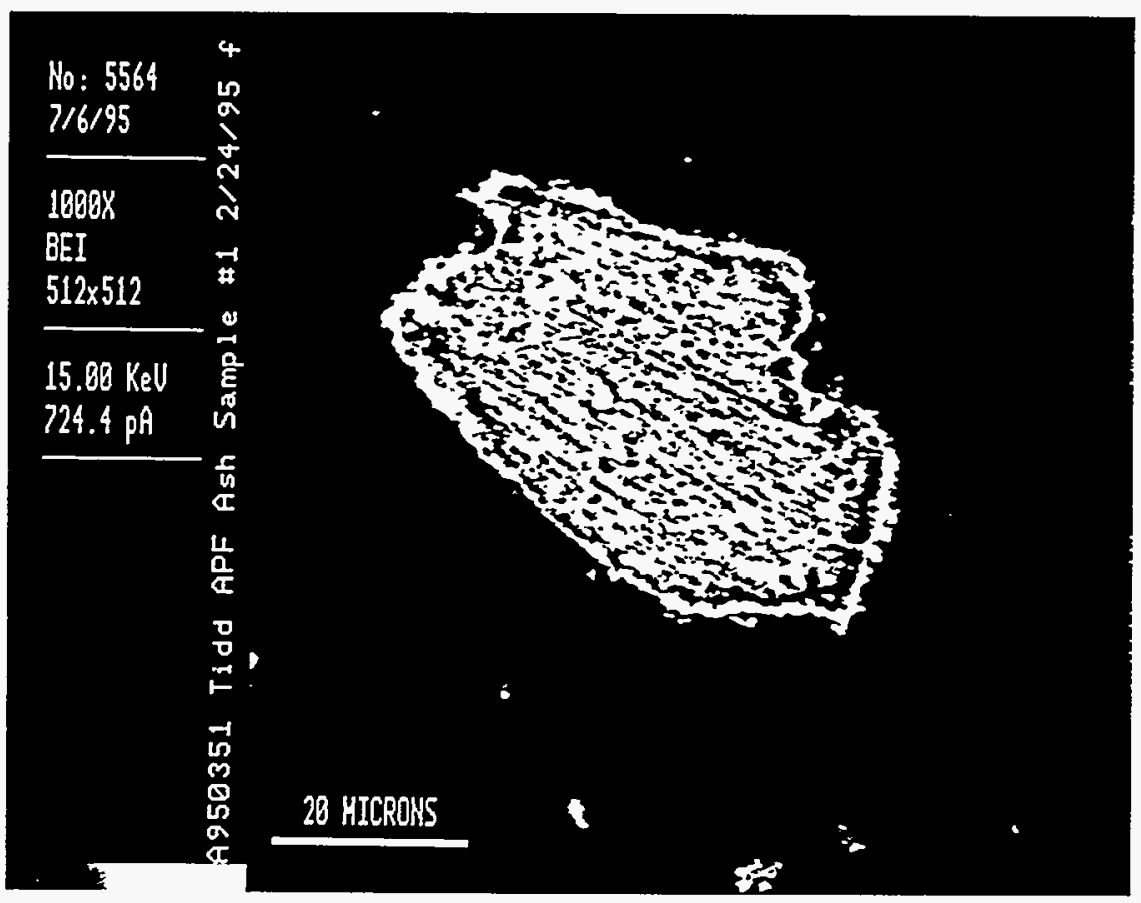

Figure 8. SEM Photo Showing a Dolomite Grain with a Rim of Sulfate from the Tidd APF Ash Collected in February 1995. 
collected in May and October 1994. The main differences included higher carbonate, $\mathrm{Ca}$, and $\mathrm{Mg}$ concentrations. The February APF ash had experienced less sulfation, probably due to the lower surface area-to-volume ratio of the larger particles. Smaller particles are more easily sulfated because of higher surface area-tovolume ratios. Also, smaller particles tend to be more sticky because of the greater influence of . factors such as Van der Waals forces. Therefore, the particle and composition distributions and the degree of sulfation of the APF ash may have an influence on ash stickiness and bridging. Further examination of the other samples, such as the cyclone and bed ashes, may also give more insight into the APF ash formation and behavior.

\section{Grimethorpe PFBC}

Four samples from the Grimethorpe PFBC archives were sent by British Coal's Coal Technology Development Division and PowerGen. The samples are filter fines from the EPRI filter during four runs at Grimethorpe between 1991 to 1992, and the run conditions are indicated in Table 4. Pressure drop across the filters during Runs 155 and 159 were relatively high because of the presence of difficult-to-clean ash on the filters. Runs 160 and 161, which used a dolomite sorbent, resulted in less problematic ash (5).

The samples were analyzed for bulk chemistry and mineralogy and will be analyzed by FPT. The objective of the analyses is to determine how the particle-size and composition distributions affect the ash behavior in the filter vessel. The bulk chemistries of the samples show reduced silica and alumina contents for Runs 159 through 161, which is probably a result of using partly clean coal (Figure 9). Unfortunately, the bulk chemistries do not show major differences between the difficult-to-clean ashes (Runs 155 and 159) and the less problematic ashes (Runs 160 and 161), indicating that more detailed analyses, such as FPT, are needed.

\section{Task 2 - Laboratory-Scale Testing}

\section{High-Temperature Tensile Strength}

Testing. The measurement of the tensile strength of powder deposits is useful for determining the magnitude of the cohesive forces that cause powders to agglomerate. Several procedures exist for determining tensile strengths of powder beds; however, available techniques allow for measurement of tensile strength only at ambient conditions. For this project, construction is under way for a testing apparatus for measuring tensile strength of ash at temperatures to $900^{\circ} \mathrm{C}$ under simulated PFBC and IGCC conditions.

Cake Sintering Tests. To determine longterm interactions between the ash and filter materials that lead to the formation of a conditioning layer of ash that remains on the filter after pulse cleaning, cylinders of filter material will be coated with ash collected from the field and sintered while allowing gas to flow through the ash cake and filter cylinder. The sintering tests will be performed in a large laboratory sintering reactor that was built under another project. The hot-gas reaction furnace (HGRF) consists of an alloy retort 9" in diameter and 6 feet long with a 48" heated length. End caps on the HGRF have ports to allow for the introduction and exhaust of gases, and measurement of pressure, temperature, and relative humidity. Shakedown runs of the HGRF have been completed, and plans are to coat filters with Tidd and Grimethorpe PFBC ashes for 500-hour exposures in a simulated $\mathrm{PFBC}$ atmosphere of $15 \% \mathrm{CO}_{2}, 15 \% \mathrm{H}_{2} \mathrm{O}$, 
Table 4. Run Conditions for the Grimethorpe Filter Samples

\begin{tabular}{|c|c|c|c|c|}
\hline Sample & Fuel ${ }^{2}$ & $\begin{array}{l}\text { Sैl } \\
\text { Sorbent }\end{array}$ & $\begin{array}{l}\text { Fititer Inlet } \\
\text { Temperature } \odot(F) \\
\end{array}$ & $\begin{array}{c}\text { Pessure Drop } \\
\text { (mbar) }\end{array}$ \\
\hline Run 155 & ROM Kiveton Park & $\begin{array}{l}\text { Middleton } \\
\text { limestone }\end{array}$ & $798(1468)$ & 360 \\
\hline Run 159 & $\begin{array}{l}\text { Partly cleaned } \\
\text { Kiveton Park }\end{array}$ & $\begin{array}{l}\text { Middleton } \\
\text { limestone }\end{array}$ & $819(1506)$ & 300 \\
\hline Run 160 & $\begin{array}{l}\text { Partly cleaned } \\
\text { Kiveton Park }\end{array}$ & Cadeby dolomite & $828(1522)$ & $<20$ \\
\hline Run 161 & $\begin{array}{l}\text { Partly cleaned } \\
\text { Kiveton Park }\end{array}$ & Cadeby dolomite & $840(1544)$ & $<20$ \\
\hline
\end{tabular}

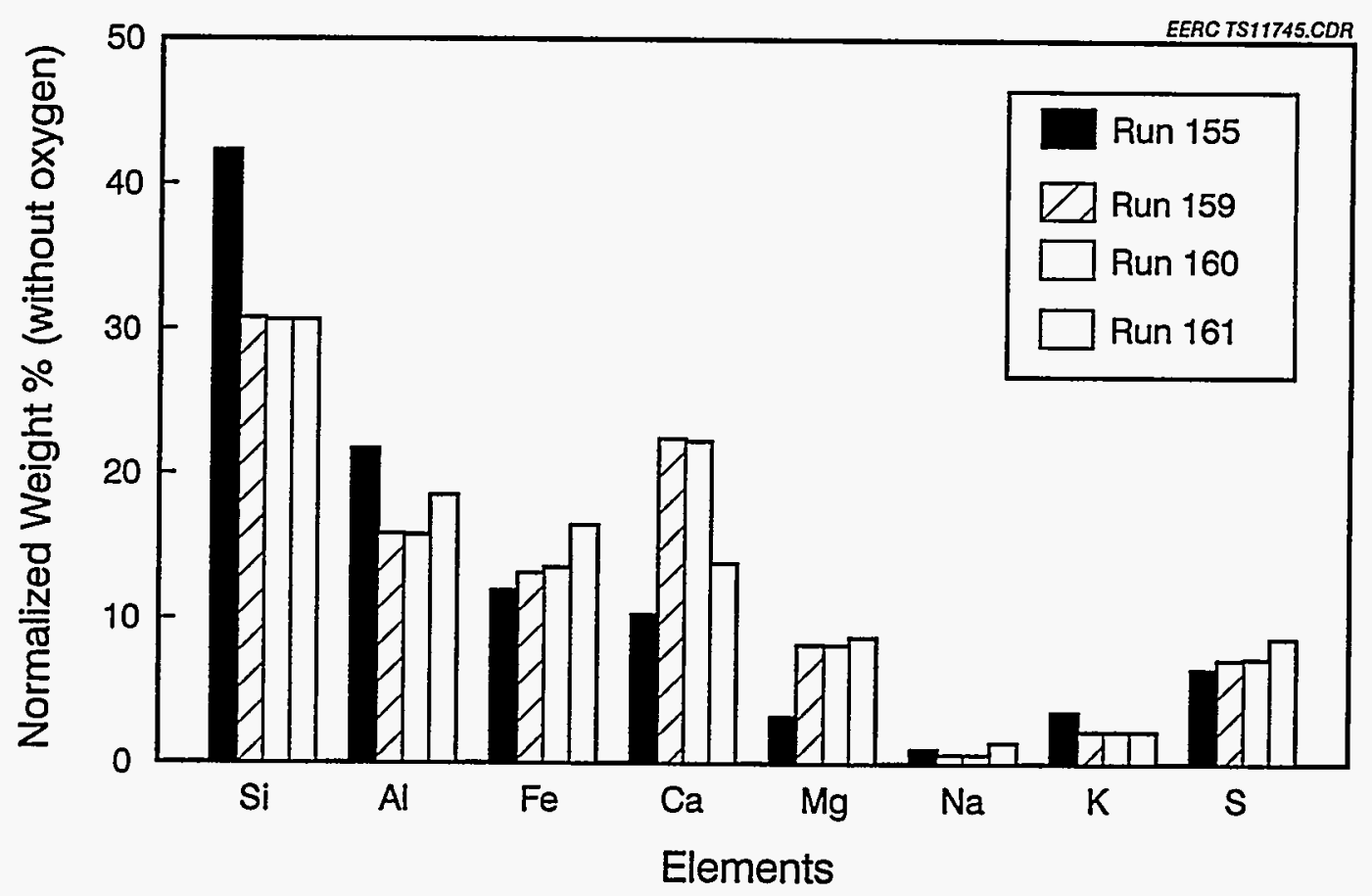

Figure 9. XRF Results for the Grimethorpe Filter Ashes 
$3 \% \mathrm{O}_{2}, 0.5 \% \mathrm{SO}_{2}$, and $0.05 \% \mathrm{HCl}$ in a balance of nitrogen. The gas stream will also be laden with $10 \mathrm{ppm}$ of $\mathrm{NaCl}$ in solution with the water. The objective of the lab-scale sintering tests is to determine the rates and mechanisms of ash sintering and ash filter interactions as functions of system conditions, ash properties, and time.

\section{Task 3 - Bench-Scale Testing}

The objective of this task will be to determine the factors affecting the final particlesize and composition distribution of the ash and to determine the ash-related factors affecting the efficiency of pulse-jet cleaning of the filter. Two bench-scale facilities will be used for parametric testing under pressurized gasification or fluidized-bed combustion conditions. The first is the $4-\mathrm{lb} / \mathrm{hr}$ continuous fluid-bed reactor (CFBR), and the second is the $7-15-\mathrm{lb} / \mathrm{hr}$ pressurized fluidized-bed reactor (PFBR). The reactors will be used for the generation of ash under realistic'operating conditions so that the factors affecting the chemical and physical properties of the ash can be determined. Tests of up to $100 \mathrm{hr}$ each will be performed on three filter types under both combustion and gasification conditions. Combustion tests will be performed under conditions simulating the Tidd PFBC, and gasification tests will be performed under conditions simulating the British Coal gasifier and the Demkolec Shell gasifier.

\section{Task 4-Computer Modeling}

The objective of this task is to develop a technique to predict a priori the ability to clean the filter cake for a given fuel, bed material, and operating condition. In this task, data collected during the first three tasks will be correlated and the best set of predictive criteria developed. Testing and analytical data will be used to modify existing computer algorithms and create new ones that will be tied together into a userfriendly computer model, which can be used to predict the approximate rate of filter blinding and bridging for a given fuel, bed material, and set of operating conditions.

\section{FUTURE WORK}

Near-term work will include continued characterization of the Grimethorpe and Tidd samples and development of the FPT. Work will begin on determining high-temperature tensile strength of both the Tidd and Grimethorpe ashes in the laboratory. Also, long-term laboratory sintering tests will be performed. Cylinders of filter material will be coated with ashes collected from both the Tidd $\mathrm{PFBC}$ and the Grimethorpe PFBC and sintered under simulated $\mathrm{PFBC}$ environments to determine the long-term interactions between the ash and filter leading to the formation of a difficult-to-remove ash layer. Bench-scale activities will commence by Fall 1995 . In the long term, we intend to collect and analyze ashes from hot-gas filter test facilities all over the world.

\section{REFERENCES}

1. Hafer, D.R.; Mudd, M.J.; Bauer, D.A.; Stogran, H.K. "AEP's Tidd PFBC Demonstration Plant: Start-Up and Operating Experience," In Proceedings of the Application of Fluidized-Bed Combustion for Power Generation; Cambridge, MA, Sept. 23-25, 1992; pp 19-1 to $19-17$.

2. Anderson, J.R.; Aggett, F.J.; Buseck, P.R.; Germani, M.S.; Shattuck, T.W. "Chemistry 
of Individual Aerosol Particles from

Chandler, Arizona, An Arid Urban

Environment," Environ. Sci. \& Technol.

1992, 22, 811-818.

3. Jones, M.L.; Kalmanovitch, D.P.;

Steadman, E.N.; Zygarlicke, C.J.; Benson,

S.A. "Application of SEM Techniques to the Characterization of Coal and Coal Ash

Products," In Advances in Coal

Spectroscopy; Meuzelaar, M.L.C., Ed.;

Plenum Publishing Co.: New York, 1989.

4. Katrinak, K.A.; Brekke, D.W.; Hurley, J.P.

"Freeze-Dried Dispersions for Automated

Scanning Electron Microscope Analysis of

Individual Submicron Airborne

Particulates," In Proceedings for the 50th

Annual Meeting of the Electron

Microscopy Society of America; San

Francisco Press, Inc.: San Francisco, 1992;

pp 408-409.

5. Lowe, T.M.; Oakey, J.E. "Evaluation of

Filter Materials Exposed in the EPRI Filter

During the Grimethorpe Topping Cycle

Project," EPRI Specific Task Report

prepared under Contract RP1336-08

Amendment No. 5 , in press. 